together the original data in order to compare the light pressure upon a vane of clear glass with that upon a silvered surface.

The experiment may be here recalled, A torsion balance carrying a thin vertical glass vane, $14 \times 10 \times 0.1 \mathrm{~mm}$. silvered on one side, was suspended in a bell jar, and the air was pumped out until the pressure was about $40 \mathrm{~mm}$. of mercury. A beam of light was thrown upon this vane at a definite distance from the rotation axis, and by turns on each side of it. The deflections were read by a telescope and scale. A Nernst lamp was used as a source, the intensity being given by a precision wattmeter. The balance was then turned through $180^{\circ}$ by the rotation of the external control magnet, and readings were again taken. The mean was proportional to the pressure of the incident and reflected beam. The mean reflection coefficient of air-silver and air-glass-silver for the radiation used has been found to be 85 per cent. The pressure, according to Maxwell.'s theory, should therefore be 1.85 times that due to the incident beam. The throw obtained (containing certainly less than I per cent. of gas action) was 22.8 divisions. Hence the pressure of the standard beam upon a black surface would be $22.8 \div \mathrm{I} .85$ or 12.4

The balance was then taken from the bell jar, the silver removed from the vane, and the glass surface cleaned. The balance was then replaced, and the air pumped out as before. The deflections were small, only about $2 \mathrm{~mm}$., and therefore could not be read to a greater accuracy than 5 per cent. The throw obtained for standard lamp was 2.I divisions (the mean of forty observations at four different air pressures).

The normal reflection coefficient of glass $(\mu=1.52)$ for this kind of radiation is $4 \cdot \mathrm{I}$ per cent. The amount reflected from the two surfaces is approximately $8 \cdot 2$. per cent. Hence the energy per unit volume in front of the glass is about 1.082 times that of the incident beam, and that behind the vane (since the absorption is negligible) is 0.918 times that of the incident beam. The former quantity is greater than the latter by 16.4 per cent. of the energy of the incident beam. Assuming that the pressures on the front and back surfaces of the glass are proportional to the energies per unit volume, the pressure of the standard beam upon a black surface would be $2.1 \div 0.164$ or 12.7 . The agreement between this result and the similar result obtained from the silvered surface shows that light passing through a plate of glass exerts pressures upon the surfaces equal to the difference between the energies per unit volume in front of and behind these surfaces.

Dartmouth College, Hanover, N.H., U.S.A

\section{The Habits of Testacella.}

UNTIL reading Mr. Latter's letter in this week's NATUR I was unaware that it was not a matter of common knowledge that Testacella appears on the surface during heavy rains. My garden is liable to be flooded, as also, unhappily, is much of this neighbourhood, in spring and late autumn. After the water has stood for a few days the ground is covered by hundreds of these slugs, which leave their burrows and try to find dry quarters. They can survive, however, a. week's immersion. In June, I903. when much of the Thames valley. was flooded, I collected a number of these slugs for various malacological friends. In normal circumstances they live at such a depth as never to be unearthed during garden operations.

Eton College, Windsor.

M. D. HiLL.

\section{NATURE AND MAN.}

PROF. LANKESTER in his Romanes lecture began by a statement of the theory of evolution, directing attention to unwarranted inferences commonly drawn by clever writers unacquainted with the study of nature. He described how the change in the character of the struggle for existence, possibly in the Lower Miocene period, which favoured an increase in the size of the brain in the great mammals and the horse, probably became most important in the development of man. The progress of man cut him off from the general operation of the law of natural selection as it had worked until he appeared, and he acquired knowledge, reason, self-consciousness, and will, so that "survival of the fittest," when applied to man, came to have a meaning quite different from what it had when applied to other creatures. Thus man can control nature, and the " nature-searchers," the founders of the Royal Society and their followers, have placed boundless power in the hands of mankind, and enabled man to arrive at spiritual emancipation and freedom of thought. But the leaders of human activity at present still attach little or no importance to the study of nature. They ignore the penalties that rebellious man must pay if he fails to continue his study and acquire greater and greater control of nature.

Prof. Lankester did not dwell upon the possible material loss to our Empire which may result from neglect of natural science; he looks at the matter as a citizen of the world, as a man who sees that within some time, it may be only roo years, it may be 500 years, man must solve many new problems if he is to continue his progress and avert a return to nature's terrible method of selecting the fittest. It seems to us that this aspect of the question has never been fully dealt with before. Throughout Huxley's later writings the certainty of a return to nature's method is always to be felt. Prof. Lankester has faith in man's power to solve those problems that seem now to be insoluble, and surely he is right.

The dangerous delay now so evident is due to the want of nature knowledge in the general population, so that the responsible administrators of Government are suffered to remain ignorant of their duties. Prof. Lankester shows that it is peculiarly in the power of such universities as Oxford and Cambridge, which are greatly free from Government control, to establish a quite different state of things from that which now obtains in England. He says :-.." The world has seen with admiration and astonishment the entire people of Japan follow the example of its governing class in the almost sudden adoption of the knowledge and control of Nature as the purpose of national education and the guide of State administration. It is possible that in a less rapid and startling manner our old Universities may, at no distant date, influence the intellectual life of the more fortunate of our fellow citizens, and consequently of the entire community." Considering Oxford more particularly, and speaking for others as well as himself, he says :- "The University of Oxford by its present action in regard to the choice and direction of subjects of study is exercising an injurious influence upon the education of the country, and especially upon the education of those who will hereafter occupy positions of influence, and will largely determine both the action of the State and the education and opinions of those who will in turn succeed them." As to Greek and Latin studies, he says:- "We have come to the conclusion that this form of education is a mistaken and injurious one. We desire to make the chief subject of education both in school and in college a knowledge of Nature as set forth in the sciences which are spoken of as physics, chemistry, geology and biology. We think that all education should consist in the first place of this kind of knowledge, on account of its commanding importance both to the individual and to the community. We think that every man of even a moderate amount of education should have acquired a sufficient knowledge of these subjects to enable him at any rate to appreciate their value, and to take an interest in their progress and application to human life." He points out that it is only in the,

No. I861, voL. 72$]$ 
last hundred years that the dogma of compulsory Greek and the value of what is now called a classical education has been promulgated. Previously, Latin was learnt because all the results of the studies of natural philosophers were in that language.

It is evident that Prof. Lankester includes in his study of nature the study of intellectual and emotional man through history, biography, novels, and poetry, but we think that he made a tactical mistake when he neglected to state this clearly. It seems to us that besides the study of nature, the most important thing in a child's education is to make him fond of reading in his own language, for this leads to a future power to make use of books and self-education for the rest of his life. When Prof. Lankester doubts the value of the study of history he is evidently doubting the value of that study as carried on at Oxford, and surely no person who has read the scathing criticism of Prof. Firth will disagree with him. When he speaks of a reform being possible, it may be that he is taking into account a movement of which but little is known outside Oxford itself, the growing indignation of the average undergraduate at being made to pay extravagant sums of money for tuition which is mischievous.

The readers of NATURE are well acquainted with the views put forward in this address. Huxley and many others, dwelling, perhaps, more upon material loss to our Empire, have published them over and over again, but we do not think that anybody has ever presented them with so much grace of style or so much of an endeavour to secure the goodwill of his audience as Prof. Lankester. But, alas! we fear that this fine address will share the fate of many others!

When, thirty-three years ago, Japan began her new career, there were a few people like Ito clever enough to see and say that the study of ancient classics alone, to the neglect of the study of nature, meant ruin to the country; but such ideas would never have been adopted had not Japan been in deadly peril. All the nations of Europe bullied and insulted her, and it was only their mutual jealousies which saved her from complete subjugation. In the presence of that peril the pedants held their peace, and everybody saw the necessity for an immediate, radical reform. In time nature was studied by every child in Japan, and in consequence scientific methods of thinking and acting have permeated the whole nation. All ancient and modern European literature is open to the Japanese who knows English, and English is the one language other than Japanese which every cultured man must know. In the matter of self-protection, anyone can see the result. Because the Japanese have studied nature their scientific officers and men have marched or sailed to victory in every engagement; their statesmen will do exactly what is best for Japan in the negotiations for peace; their country will quietly take its place as one of the first-class Powers of the world, and every person who knows anything about Japan is quite sure that ambitious, wrong-headed schemes of conquest are altogether impossible to the scientific minds of the Japanese.

If Japan had not been in great danger we know that she would not have taken to nature-study, and some of us think that it may need a state of danger in England to produce the necessary desire for reform. The South African muddle was worried through, and almost everybody seems to think that all such muddles may also be worried through, but some of us think that we may not always be so lucky. Danger is close enough even now, and we can only hope that if it becomes great it may grow slowly enough to let us learn something from the object lesson which is being NO. I $86 \mathrm{I}$, VOL. 72$]$ given us day by day in the news from Russia and the Far East.

Fain would we hope that Oxford will pay attention to what has been said by one whom some of us regard as her cleverest son; but, alas! we have no such hope. Oh, Shade of Clough, how can we help saying that " the struggle nought availeth" when your own best admirers seem unable to think for themselves?

John Perry.

\section{A LIFE'S WORK IN THE THEORY OF EVOLUTION. ${ }^{1}$}

$\mathrm{I}$ this elaborate and carefully written treatise the veteran biologist of Freiburg has brought together and presented in connected form the fruit of his life-long investigation of the principles and methods of organic evolution. It would be an easy matter to show-indeed, the author admits as much with perfect candour-that his present standpoint differs in many important respects from that adopted by him at former periods of his career. The fact that Weismann has more than once shifted his ground has often been brought against him as a kind of reproach-we think with scant justice; for in a subject like the present, where new facts come crowding upon us almost daily, it is unreasonable to expect that a far-reaching theory should at once attain finality. If the author of such a theory should be willing to recognise that some parts of it become untenable and others require modification in the light of fresh discoveries, this should be reckoned to his credit rather than otherwise. The practice of putting forward illconsidered and hasty views deserves severe condemnation; but it is characteristic of our author that even his boldest speculations rest for the most part on a basis of observed fact, and that he has always honestly striven to render his theory consistent both with itself and also with the new facts that have from time to time come under the observation of other investigators. Moreover, his plan of, so to speak, taking the scientific world into his confidence, and enabling his colleagues to follow the workings of his own mind, has not only added greatly to the interest of his contribution to the biological thought of our time, but has acted also as a powerful stimulus to fellow-workers in the same field. So much may fairly be said, whether his final conclusions meet with general acceptance or the reverse.

The first eleven chapters of the present book traverse familiar ground. Starting with a brief historical account of evolutionary theory up to and including the work of Darwin and Wallace, they proceed to a more detailed discussion of such branches of the subject as the coloration of animals, mimicry, instinct, symbiosis, protective adaptations in plants, the origin of flowers, and sexual selection. These are well-worn topics, but their treatment is interesting and by no means trite. Next comes a discussion of Roux's suggestion of the "Kampf der Theile " which strikes us as somewhat of an excrescence on the general structure of the treatise. The existence of a metabolic response to functional stimulus is undeniable, but we do not think that either Roux or Weismann has plumbed the matter to the bottom, and the latter author's use of the term "selection" in this connection appears to involve some overstrain of language. 1 "Vorträge iber Deszendenztheorie gehalten an der Universität zu
Freiburg im Breisgau." By Prof. A August Weismann. Second revised edition. 2 vols. Pp. xii +340 ; vi +344 . (Jena: Gustav Fischer, rgo4.) Price to marks.

"The Evolution Theory." By Prof. August Weismann. Translated with the author's co-operation by Prof. J. Arthur Thomson and Margaret R. Thomson. 2 vols. $\mathrm{Pp}$. xvi $+4 \mathrm{r} 6$; iv +405 ; illustrated. (London Edward Arnold, rgo4.) Price 32s, net 